Natanael Jeffrey - 672020027

\title{
Analisis Jurnal
}

\section{A. IDENTITAS JURNAL (Jangan sampai salah menulis Identitas Jurnalnya)}

1. Nama Jurnal : Evangelikal: Jurnal Teologi Injili dan Pembinaan Warga Jemaat

2. Volume : 3

3. Nomor : 1

4. Halaman : 100-112

5. Tahun Penerbit : 2019

6. Judul Jurnal : Gereja dan Kemiskinan: Diskursus Peran Gereja di Tengah Kemiskinan

7. Nama Penulis : Fibry Jati Nugroho

\section{B. ISI JURNAL}

1. Masalah Penelitian

Kemiskinan merupakan masalah sosial tidak hanya lokal namun telah menjadi tantangan dunia. Peran gereja dalam mengatasi kemiskinan yang dinilai tidak maksimal karena berbagai macam kesalahan persepsi.

2. Metode Penelitian

Penulis menggunakan pendekatan kualitatif dengan metode deskriptif analisis yang dilakukan untuk mengetahui nilai variabel mandiri, baik satu variabel atau lebih (independen) tanpa membuat perbandingan atau dengan menghubungkan antara variabel yang satu dengan variabel yang lainnya.

3. Teori yang dipakai

Teori yang digunakan bersumber dari ajaran kekristenan berdasarkan firman dalam Alkitab dan teori dari Karl Marx.

4. Hasil Penelitian

- Menurut pandangan kritis dari Karl Marx pada masa itu, dimana kaum kaya mempengaruhi perekonomian dengan mengaitkan agama. Sehingga agama disebut sebagai candu masyarakat yang mengubah cara berpikir manusia dalam kaitannya kemiskinan dan kekayaan. hal ini menyebabkan terjadinya kesenjangan sosial antar kaum kaya dan kaum miskin. Ada sebuah relevansi teori tersebut dengan kehidupan sekarang yang perlu dibenahi.

- Kemiskinan menjadi perhatian dunia terutama pada negara yang sedang berkembang, terutama di Indonesia. Walaupun negara ini memiliki potensi besar dalam sumber daya alam nya, namun kemiskinan tetap menjadi persoalan umum di tengah masyarakat.

- Gereja memiliki tugas dan panggilan untuk berpihak pada kaum miskin dan lemah dengan membawa teladan yang Yesus ajarkan. 
- Gereja harus mendorong jemaat-jemaatnya supaya memiliki kepedulian dan kesetiakawanan terhadap orang-orang miskin.

- Gereja sebagai mandataris Tuhan di dunia harus menjadi Terang dan Garam ditengah masyarakat dan menjadi solusi di setiap pergumulan yang ada.

\section{KELEBIHAN DAN KEKURANGAN}

1. Kelebihan

Menurut saya penulis mampu menyajikan kritik dengan lugas dan sistematis disertai data-data yang komprehensif sesuai realitas yang ada, mampu mengutip pernyataan kritis Karl Marx dengan rapi sesuai dengan pembahasan utama, dan mampu memberi nasihat sekaligus solusi bagi gereja dalam menghadapi kemiskinan.

2. Kekurangan

Ada kesalahan penulisan dalam bab pendahuluan kutipan ayat Filipi 1:7 yang seharusnya diambil dari Filipi 1:5. 